\title{
Efektivitas antibakteri ekstrak daun sirih (Piper betle Linn) terhadap bakteri Enterococcus faecalis (Antibacterial effectiveness of betel leaf extract (Piper Betle Linn) to Enterococcus faecalis)
}

\author{
${ }^{1}$ Armianty, ${ }^{2}$ Indrya Kirana Mattulada \\ ${ }^{1}$ Mahasiswa tahap profesi \\ ${ }^{2}$ Bagian Konservasi Gigi \\ Fakultas Kedokteran Gigi Universitas Hasanuddin \\ Makassar, Indonesia
}

\begin{abstract}
Enterococcus faecalis is one of bacteria which have resistance against the pulp tissue defense mechanism and often found in endodontic infections. This bacterial is may hold good colonization, can survive in the root canal without other bacteria, and is capable of producing toxins directly or through the induction of inflammation. Betel leaf (Piper betle Linn) contain essential oils, as the main components of the essential oils are phenols and compounds, among other derivate such as kavikol compound that has bactericidal five times stronger than phenol. Phenol disrupts three dimensional structure of the bacterial protein to be a random structure and denatured protein, and damages biological activity. Chlorhexidine has been shown to be effective against Enterococcus in the root canal irrigation. Betel leaf can be chosen as an alternative material root canal irrigation saline. This in vitro experimental laboratory study is aimed to determine the effectiveness of anti-bacterial extracts of betel leaf for E.faecalis bacteria. The minimum inhibitory concentration of betel leaf extract is determined by observing the lowest concentration that was first seen clearly, namely 20\%. The assay method of these anti-bacterial effect used diffusion method to comparing the inhibition zone betel leaf extract solution in concentration of $20 \%$ be compared $0.2 \%$ chlorhexidine, $2 \%$ chlorhexidine, and distilled water. Each group performed eight times repetition respectively. Data analysis used one way anova test followed by LSD test. From this research, it was concluded that $2 \%$ chlorhexidine has antibacterial effect for E.faecalis better than betel leaf extract and $0.2 \%$ chlorhexidine.
\end{abstract}

Keywords: Entercoccus faecalis, betel leaf extract, $0.2 \%$ chlorhexidine, and $2 \%$ chlorhexidine

\begin{abstract}
ABSTRAK
Enterococcus faecalis adalah bakteri yang memiliki resistensi dalam melawan mekanisme pertahanan jaringan pulpa dan sering ditemukan pada infeksi endodontik. Bakteri ini dapat berkolonisasi secara baik, bertahan dalam saluran akar tanpa bakteri lainnya, serta mampu memproduksi toksin secara langsung maupun melalui induksi inflamasi. Daun sirih (Piper betle Linn) mengandung minyak atsiri dengan komponen utamanya fenol dan senyawa turunannya; diantaranya adalah kavikol yang memiliki daya bakterisida lima kali lebih kuat dibandingkan fenol. Fenol mengganggu struktur tiga dimensi protein bakteri sehingga menjadi struktur acak, protein terdenaturasi dan aktivitas biologis menjadi rusak, sehingga pertumbuhan E.faecalis terhenti. Klorheksidin telah terbukti efektif melawan Enterococcus dalam proses irigasi saluran akar. Penelitian eksperimen laboratorium ini dimaksudkan untuk mengetahui efektivitas antibakteri ekstrak daun sirih terhadap E.faecalis. Konsentrasi hambat minimal (KHM) ekstrak daun sirih ditentukan dengan melihat konsentrasi terendah yang pertama kali terlihat jernih; yaitu 20\%. Metode difusi dilakukan untuk membandingkan zona inhibisi larutan ekstrak daun sirih dibandingkan klorheksidin $0,2 \%$ dan $2 \%$, dan akuades; dengan pengulangan delapan kali. Data dianalisis dengan uji analisis varian satu arah, kemudian dilanjutkan dengan uji LSD. Dari hasil penelitian, disimpulkan bahwa klorheksidin 2\% memiliki daya antibakteri lebih baik terhadap E.faecalis dibandingkan dengan ekstrak daun sirih $20 \%$ dan klorheksidin 0,2\%.
\end{abstract}

Kata kunci: Entercoccus faecalis, ekstrak daun sirih, klorheksidin $2 \%$, klorheksidin 0,2\%

Koresponden: Armianty. E-mail: ditha_harman@yahoo.co.id

\section{PENDAHULUAN}

Hampir semua penyakit endodontik, baik itu penyakit pulpa atau pun penyakit periradikuler disebabkanoleh adanya bakteri. ${ }^{1}$ Lebih dari 700 jenis spesies bakteri ditemukan dalam rongga mulut. Lewat beberapa penelitian telah terbukti bahwa hampir $90 \%$ bakteri yang ditemukan di saluran akar terinfeksi merupakan bakteri anaerob, ${ }^{2}$ salah satu contohnya ialah bakteri Enterococcus faecalis.

Tingkat keberhasilan suatu perawatan endodontik dipengaruhi oleh beberapa hal, antara lain cleaning dan shaping, pengisian saluran akar secara hermetik, serta pemilihan bahan yang memiliki dimensi stabil dan kompatibel terhadap jaringan. Salah satu tahapan perawatan cleaning dan shaping yang dianggap penting adalah irigasi, untuk membersihkan saluran akar dari debris dan smear layer, sebelum dilakukan pengisian. ${ }^{3}$

Awalnya klorheksidin digunakan secara luas sebagai obat kumur penghambat plak gigi oleh Loe 
dan Schiott. Pada tahun 1997, klorheksidin digunakan secara lokal untuk mengurangi kedalaman poket penderita periodontitis. Ferraz membuktikan bahwa klorheksidin dapat juga digunakan sebagai bahan irigasi saluran akar. ${ }^{4}$

Selain klorheksidin, ada beberapa bahan alami yang dikembangkan sebagai bahan antimikroba; yang khusus dikembangkan sebagai bahan irigasi saluran akar alternatif ialah daun sirih (Piper betle Linn). Daun sirih diketahui mempunyai efek antibakteri terhadap beberapa jenis bakteri, salah satunya adalah Streptococcus mutans. Pada daun sirih terkandung minyak atsiri yang komponen utamanya adalah fenol dan senyawa turunannya, antara lain adalah klavikol yang memiliki daya bakterisida lima kali lebih kuat dibanding fenol. ${ }^{5}$

Penelitian ini dimaksudkan untuk menguji dan membandingkan pengaruh antibakteri bahan irigasi saluran akar antara klorheksidin $0,2 \%$ dan $2 \%$, serta ekstrak daun sirih terhadap bakteri E.faecalis.

\section{BAHAN DAN METODE}

Penelitian eksperimen laboratorium dengan desain post test control group ini dilaksanakan di Laboratorium Mikrobiologi Fakultas Kedokteran (FK) dan Laboratorium Fitokimia Fakultas Farmasi (FF) Universitas Hasanuddin (Unhas). Pengujian konsentrasi hambat minimal (KHM) dilakukan dengan melakukan metode dilusi serta uji antibakteri menggunakan metode difusi.

Variabel penelitian meliputi variabel bebas, yaitu daun sirih, klorheksidin $0,2 \%$, klorheksidin $2 \%$, variabel terikat yaitu bakteri $E$.faecalis dan variabel kontrol, yaitu lamanya waktu inkubasi, temperatur inkubasi, konsentrasi larutan uji dan jumlah tetesan.

\section{Pembuatan ekstrak daun sirih}

Daun sirih hijau yang segar dari Kabupaten Gowa, dipetik sebanyak $800 \mathrm{~g}$ lalu dibersihkan dari kotoran, dicuci dengan air hingga bersih lalu ditiris. Selanjutnya, daun sirih tersebut dikeringkan dengan menggunakan oven pada suhu $40-50^{\circ} \mathrm{C}$, lalu dipotongpotong kemudian ditimbang dengan menggunakan timbangan simplisia (Sartorium, USA) sebanyak 140 g. Ekstrak dibuat dengan cara maserasi, yaitu merendam daun sirih di dalam bejana maserasi secara terpisah kemudian diberi larutan etanol 96\% sampai daun terendam sempurna. Bejana maserasi tersebut ditutup rapat dan didiamkan selama sekitar 2 hari sambil diaduk satu kali setiap hari. Hasilnya disaring dan diulang sebanyak tiga kali,kemudian ditampung dalam botol untuk selanjutnya dipekatkan dengan menggunakan alat rotary evaporator (Buchner, Germany), sampai diperoleh ekstrak etanol kental.
Selanjutnya, ekstrak yang diperoleh diuapkan dengan menggunakan alat rotary evaporator pada suhu $70^{\circ} \mathrm{C}$ untuk menguapkan etanol sehingga diperoleh ekstrak kental daun sirih.

\section{Penentuan KHM ekstrak daun sirih}

Ekstrak daun sirih diencerkan dengan rumus $\mathrm{m}=\mathrm{M} \mathrm{x} \mathrm{V} \mathrm{(m:} \mathrm{massa} \mathrm{daun} \mathrm{sirih} \mathrm{(g),} \mathrm{M:} \mathrm{konsentrasi}$ larutan $(\mathrm{g} / \mathrm{ml})$, V: volume larutan $(\mathrm{mL}))$. Untuk memperoleh ekstrak daun sirih konsentrasi $10 \%$, $15 \%, 20 \%$, 25\%, dan 30\%, ekstrak daun sirih ditimbang berturut-turut sebanyak $1 \mathrm{~g}, 1,5 \mathrm{~g}, 2 \mathrm{~g}$, $2,5 \mathrm{~g}$, dan $3 \mathrm{~g}$, kemudian dilarutkan dengan akuades sebanyak $10 \mathrm{~mL}$. Lima buah tabung (Pyrex, USA) disiapkan dan diisi dengan media brain heart infusion broth (BHIB)(Laboratorium MikrobiologiFKUnhas) sebanyak $5 \mathrm{ml}$. Kemudian 0,2 ml bakteri E.faecalis (Lab. Mikrobiologi FK Unhas) dimasukkan pada masing-masing tabung. Setelah itu, masing-masing ekstrak yang telah diencerkan tersebut dimasukkan ke dalam tabungnya, kemudian diberi label sesuai konsentrasinya. Semua tabung diinkubasi (Memmert, Jerman) pada suhu $37^{\circ} \mathrm{C}$ selama 24 jam, selanjutnya dilakukan pemeriksaan ada tidaknya pertumbuhan bakteri, yang ditandai dengan terjadinya kekeruhan dalam tabung. Penentuan KHM dilakukan dengan memperhatikan tabung dengan konsentrasi yang pertama terlihat jernih. Tabung yang terlihat keruh menunjukkan masih adanya pertumbuhan bakteri. Tabung yang pertama kali terlihat jernih merupakan konsentrasi daun sirih yang akan digunakan pada pengujian terhadap bakteri E.faecalis.

\section{Uji efek antibakteri klorheksidin dan ekstrak daun sirih terhadap bakteri $E_{\text {. }}$ faecalis}

Alat-alat disiapkan dan disterilkan dengan otoklaf (Hirayama, Jepang). Enambelas buah cawan petri (Pyrex, USA), yang berisi media Mueller Hinton Agar (MHA) (Merck, Germany) disiapkan. Masukkan bakteri Enterococcus faecalis, Cotton swab dicelupkan dalam biakan bakteri kemudian kapas ditekan pada sisi tabung agar tiris. Cotton swab diulaskan pada seluruh permukan cawan petri yang berisi medium secara merata. Tiga puluh dua buah paper disc, yang masing-masing dibagi empat kelompok untuk daun sirih, klorheksidin 0,2\% (Minorck, Surabaya Indonesia), klorheksidin 2\% (Consepsis, Germany), dan akuades ke dalam 16 cawan petri. Kedalam masing-masing cawan petri diletakkanempat buah paper disk. Empat buah paper disc tersebut diletakkan pada permukaan media yang terdapat biakan bakteri E,faecalis, kemudian ditekan dengan menggunakan pinset agar paper disc benar-benar menempel pada media, setelah itu 
paper disc tersebut ditetesi masing-masing larutan klorheksidin $0,2 \%$, klorheksidin $2 \%$, akuades dan ekstrak daun sirih konsentrasi sesuai KHM sebanyak satu tetes $(10 \mu \mathrm{L})$ dengan menggunakan micropipet (Socorex, Germany). Cawan petri tersebut diinkubasi dengan temperatur $37^{\circ} \mathrm{C}$ selama $3 \times 24$ jam. Untuk mengetahui daya hambatnya dilakukan pengukuran zona inhibisi, yaitu daerah jernih pada permukaan media MHA, di sekitar paper disc menggunakan kaliper (Mitutoyo, Jepang).

\section{HASIL}

Dari hasil penelitian penentuan KHM ekstrak daun sirih terhadap bakteri E.faecalis ditunjukkan data antara lain seperti yang nampak pada tabel 1 . Tampak dari media BHIB setelah diberi ekstrak daun sirih selama 72 jam terdapat dua konsentrasi yang mengalami kekeruhan, yaitu konsentrasi $10 \%$ dan $15 \%$. Sedangkan yang tidak mengalami kekeruhan terdapat pada konsentrasi $20 \%, 25 \%$, dan $30 \%$. Berdasarkan pengujian tersebut ditentukan bahwa KHM ekstrak daun sirih pada konsentrasi $20 \%$.

Pada penentuan KHM dari ekstrak daun sirih maka dilakukan pengujian efek antibakteri terhadap bakteri Enterococcus faecalis. Dalam penelitian ini dilakukan pengukuran zona hambat yang terbentuk pada permukaan media biakan bakteri (tabel 2 dan gambar 2).

Hasil uji statistik yang telah dilakukan untuk mengetahui perbedaan diameter zona hambat antara ekstrak daun sirih, klorheksidin $0,2 \%$, klorheksidin

Tabel 1 Tingkat kekeruhan bakteri E.faecalis pada media BHIB setelah diberi ekstrak daun sirih (piper betle Linn) selama 72 jam

\begin{tabular}{cccccc}
\hline Inkubasi & \multicolumn{5}{c}{ Ekstrak daun sirih } \\
\hline \multirow{2}{*}{72 jam } & $10 \%$ & $15 \%$ & $20 \%$ & $25 \%$ & $30 \%$ \\
& + & + & - & - & - \\
\hline$+\cdot$ keruh; - & tidak Keruh & & &
\end{tabular}

+ : keruh; - : tidak Keruh

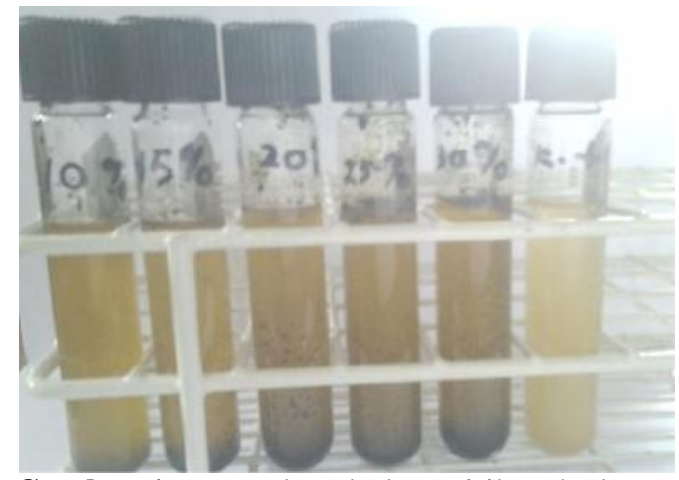

Gambar 1 KHM ekstrak daun sirih terhadap $E$. faecalis

Tabel 2 Diameter rata-rata zona hambat ekstrak daun sirih, klorheksidin 0,2\%, klorheksidin $2 \%$ dan akuades terhadap bakteri E.faecalis

\begin{tabular}{lcccc}
\hline & \multicolumn{3}{c}{ Zona hambat (mm) } \\
& Ekstrak daun sirih 20\% & Klorheksidin $0,2 \%$ & Klorheksidin2\% & Akuades \\
\hline Diameter rata-rata & 15,65 & 15,4 & 27,6 & 0 \\
\hline
\end{tabular}
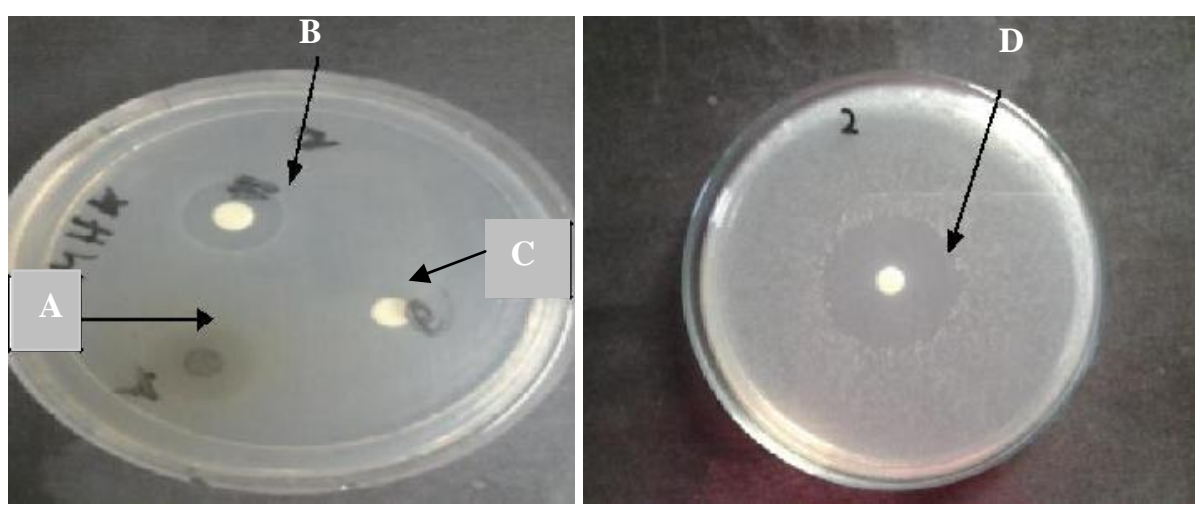

Gambar 2 Zona daya hambat daun sirih, klorheksidin 0,2\%, klorheksidin $2 \%$ dan akuades terhadap E.faecalis (A ekstrak daun sirih $20 \%$, B klorheksidin 0,2\%, C akuades, D klorheksidin $20 \%$

Tabel3 Uji anova perbedaan diameter zona hambat antara ekstrak daun sirih, klorheksidin $0,2 \%$, akuades $2 \%$, dan akuades

\begin{tabular}{lccccc}
\hline & Sum of Squares & Df & Mean Square & F & Sig. \\
\hline Between Groups & 1835.245 & 3 & 611.748 & 203.850 & .000 \\
Within Groups & 84.027 & 28 & 3.001 & & \\
Total & 1919.272 & 31 & & & \\
\hline
\end{tabular}

*= signifikan pada $\mathrm{p}=0,000 ;<0,05$ 
Tabel 4 Uji least significant difference (LSD) mengenai perbedaan diameter zona hambat antara ekstrak daun sirih, klorheksidin 0,2\%, klorheksin 2\%, dan akuades

\begin{tabular}{ccccc}
\hline (I) Kelompok & (J) Kelompok & Mean Difference (I-J) & Std. Error & Sig. \\
\hline Ekstrak daun sirih & Klorheksidin 0,2\% & 0,25000 & 0,86617 & 0,775 \\
& Klorheksidin 2\% & $-11,70625$ & 0,86617 & $0,000^{*}$ \\
& Akuades & 9,65000 & 0,86617 & $0,000^{*}$ \\
Klorheksidin 0,2\% & Klorheksidin 2\% & $-11,95625$ & 0,86617 & $0,000^{*}$ \\
& Akuades & 9,40000 & 0,86617 & $0,000^{*}$ \\
Klorheksidin 2\% & Akuades & 21,35625 & 0,86617 & $0,000^{*}$ \\
\hline *: The mean difference is significant at the 0.05 level & & &
\end{tabular}

$2 \%$, dan akuades tampak pada tabel3. Tampak Nilai signifikan $p=0,000(p<0,05)$ yang berarti terdapat perbedaan efektivitas yang bermakna antara ekstrak daun sirih, klorheksidin $0,2 \%$, klorheksidin $2 \%$, dan akuades. Pengujian dengan menggunakan anova satu arah hanya dapat menunjukkan ada tidaknya perbedaan efektivitas antibakteri antara ekstrak daun sirih, klorheksidin 0,2\%, dan klorheksidin $2 \%$ terhadap E.faecalis, untuk itu diperlukan pengujian menggunakan uji least significant difference (LSD) agar dapat diketahui besarnya perbedaan efektivitas antibakteri dari setiap kelompok.

Perbedaan signifikan terlihat bila nilai $\mathrm{p}<0,05$ pada nilai signifikansinya. Dari tabel 4 , hasil uji LSD memperlihatkan bahwa ekstrak daun sirih terhadap klorheksidin $0,2 \%$ tidak terdapat perbedaan yang signifikan $(\mathrm{p}=0,775)$, ekstrak daun sirih terhadap klorheksidin $2 \%$ terdapat perbedaan yang signifikan $(\mathrm{p}=0,000)$, ekstrak daun sirih terhadap akuades juga terdapat perbedaan yang signifikan $(\mathrm{p}=0,000)$.

\section{PEMBAHASAN}

Bakteri E.faecalis merupakan bakteri fakultatif anaerob gram positif berbentuk kokus yang memiliki dinding sel dengan peptidoglikan tebal, namun jika terjadi kerusakan maupun terjadi hambatan pada pembentukannya maka akan terjadi kematian sel tersebut. ${ }^{6}$ Salah satu bahan yang memiliki efektivitas sebagai antibakteri, yaitu tanaman sirih yang khasiat daunnya telah banyak digunakan. Efek astringen bahan ini, telah diketahui sebagai obat kumur, dan tidak menimbulkan iritasi selaput lendir rongga mulut Pada konsentrasi $20 \%$ bekerja lebih baik terhadap Streptococcus viridans. ${ }^{7}$

Berdasarkan hasil suatu penelitian, minyak atsiri daun sirih sudah menunjukkan aktivitas antibakteri terhadap Streptococcus mutans pada konsentrasi $0,1 \%$. Selain dalam bentuk larutan murni, pengujian aktivitas antibakteri dilakukan juga dalam bentuk pasta gigi. Menurutnya, pasta gigi yang mengandung minyak atsiri daun sirih menunjukkan aktivitas antibakteri terhadap S.mutans pada konsentrasi $0,1 \%{ }^{8}$
Penelitian daun sirih juga dilakukkan oleh Agustin yang menunjukkan bahwa diameter zona hambat bakteri mix oleh infusum daun sirih $20 \%$ secara bermaknalebih besar dari hidrogen peroksida $3 \%(\mathrm{p}<0,05)$, yang berarti infusum daun sirih $20 \%$ mempunyai efek antibakteri lebih kuat dari hidrogen peroksida 3\%. Infusum daun sirih mengandung minyak atsiri yang didalamnya terdapat senyawa fenol yang bersifat bakterisid. ${ }^{7}$

Hasil tersebut didukung oleh hasil penelitian ini. Berdasarkan penelitian ini diperoleh hasil bahwa ekstrak daun sirih dengan konsentrasi $20 \%$ memiliki efek antibakteri terhadap bakteri E.faecalis.

Penelitian klorheksidin 2\% juga dilakukan oleh Oktaviani yaitu mengenai perbedaan efektivitas daya antibakteri antaraklorheksidin diglukonat $2 \%$ dengan berbagai konsentrasi ekstrak buah mahkota dewa menunjukkan klorheksidin diglukonat $2 \%$ memiliki daya antibakteri lebih tinggi dibandingkan dengan ekstrak buah mahkota dewa konsentrasi 20\%, 30\%, 40\%, dan 50\% terhadap bakteri E.faecalis. ${ }^{9}$

Pada pengujian efektivitas klorheksidin $2 \%$ yang dilakukan, mendukung hasil penelitian Oktaviani, yaitu klorheksidin konsentrasi $0,2 \%$ menghambat pertumbuhan bakteri E.faecalis.

Adapun hasil penelitian yang dilakukan oleh Mangundjaja, menunjukkan efek dari berkumur klorheksidin 0,2\% selama 45 detik paling efektif menurunkan jumlah populasi S.mutans, karena memiliki kemampuan sebagai bakteriostatik dan bakterisid terhadap kuman rongga mulut terutama S.mutans di dalam saliva. ${ }^{10}$ Hal tersebut didukung dengan hasil penelitian ini, yaitu klorheksidin $0,2 \%$ memiliki efek antibakteri terhadap bakteri E.faecalis.

Berdasarkan hasil penelitian ini, didapatkan ekstrak daun sirih dan klorheksidin $0,2 \%$ mempunyai efektivitas sama dalam menghambat pertumbuhan bakteri E.faecalis. Meskipun demikian, ekstrak daun sirih dengan konsentrasi 20\% juga mempunyai efektivitas antibakteri. Dengan demikian disimpulkan bahwa ekstrak daun sirih, klorheksidin $0,2 \%$, dan klorheksidin $2 \%$ dapat menghambat pertumbuhan bakteri E.faecalis, tetapi klorheksidin $2 \%$ memiliki efektivitas lebih baik. 
Meskipun demikian, perlu dilakukan penelitian selanjutnya mengenai penggunaan klorheksidin $0,2 \%$ sebagai bahan irigasi saluran akar, karna sulitnya diperoleh klorheksidin $2 \%$, dan penggunaan ekstrak daun sirih (piper betle linn) sebagai bahan irigasi saluran akar dalam bidang kedokteran gigi.

\section{DAFTAR PUSTAKA}

1. Baumgartner JC. Microbiology aspect of endodontic infections. Calif Dent Assoc J [serial online] 2004;32(6):45960:[internet]. Available from: www.cda.org. Accessed at 16 Juni 2013.

2. Ferreira CM. da Silva ROP, Torres SA, de Andrabe FFB, Bernardinelli N. activity of endodontic antibacterial agents against selected anaerobic bacteria. Braz Dent J [serial online] 2002; 13 (2). [internet]. Available from: www.scielo.org. Accessed at 18 Juni 2013.

3. Walton RE, Rivera EM. Pembersihan dan pembentukan saluran irigasi. In: Walton Richard E, Toerbinejed M, editor. Prinsip dan praktik ilmu endodonsia. $3^{\text {rd }}$ Ed. Alih bahasa: Sumawinata N, Juwono L, editor. Jakarta: Penerbit Buku kedokteran EGC; 2008. p. 243-7.

4. Prijantojo. Peranan klorheksidin terhadap kelainan gigi dan rongga mulut. Cermin Dunia Kedokteran 1996; 113. Available from: http//www.cerminduniakedokteran.com. Accessed at 18 September 2013.

5. Nalina T, Rahim ZHA.The crude aqueous extract of Piper betel $\mathrm{L}$ and its antibacterial affect towards Streptococcus mutans. Am J Biochem Biotech 2007; 3(1):10-5.

6. Mareta DA. Sofiati E. Perbedaan daya antibakteri antara klorheksidin diglukonat $2 \%$ dengan ekstrak daun jambu biji. [skripsi]. Yogyakarta: Universitas Muhammadiyah.

7. Agustin D. Perbedaan khasiat antibakteri bahan irigasi antara hidrogen peroksida $3 \%$ dan infusum daun sirih $20 \%$ terhadap bakteri. Maj Ked Gigi (Dent J) 2005; 38(1): 45-7. Available from http://journal.unair.ac.id/filerPDF/ DENTJ-38-1-12.pdf. Accessed at 15 Desember 2012

8. Yendriwati, Henny. Efek antibakteri sediaan daun sirih (Piper betel L), obat kumur minyak essensial dan povidone iodine 1\% terhadap Streptococcus mutans. Dentika Dent J 2008;13(2):103.

9. Oktaviani W. Perbedaan efektivitas daya antibakteri antara klorheksidin diglukonat $2 \%$ dengan berbagai konsentrasi ekstrak buah mahkota dewa. [skripsi]. Yogyakarta: Universitas Muhammadiyah.

10. Mangundjaja S. Pengaruh obat kumur terhadap populasi kuman Streptococcus mutans di dalam air liur. Jakarta: Universitas Indonesia. 